\title{
PUBLIC RELATIONS SEBAGAI STRATEGI KOMUNIKASI
}

\section{PEMASARAN}

\section{Pafti E Simanullang 1)*}

1) Fakultas Ekonomi Universitas Negeri Medan E-mail: Bobstar906@gmail.com

\begin{abstract}
Pengetahuan, pemahaman, dan penerapan komunikasi pemasaran terintegrasi akan membantu tenaga penjualan untuk membantu pemasaran mereknya. Artikel ini bertujuan untuk melakukan studi teoritis antara kewirausahaan dan komunikasi pemasaran yang terintegrasi sebagai metode promosi pemasaran. Ketika dilakukan secara komprehensif, komunikasi pemasaran yang terintegrasi akan membantu seorang wirausahawan untuk membantunya memperkenalkan, membentuk kesan positif dan mempertahankan pelanggan untuk merek yang mereka miliki.
\end{abstract}

Kata Kunci : Public Relation, Pemasaran. 


\section{PENDAHULUAN}

Dikaitkan dengan keadaan dewasa ini dimana persaingan dunia usaha menunjukkan kecenderungan yang semakin meningkat berakibat jumlah penjualan produk dari waktu ke waktu akan mengalami pasang surut. Gelombang naik turunnya penjualan tersebut dapat kecil dan dapat pula semakin besar. Kenyataan inilah yang mengundang perusahaan untuk berpikir faktor apakah yang dapat mempengaruhi perkembangan penjualan produknya. Besar kecilnya perkembangan penjualan pada hakikatnya dipengaruhi dua faktor utama, yaitu faktor ekstern dan faktor intern. Faktor eksteren merupakan faktor yang tidak dapat dikendalikan oleh perusahaan, faktor tersebut berupa antara lain: situasi perekonomian, kebijakan pemerintah, keadaan pesaing serta selera dari konsumen itu sendiri. Sedangkan faktor internal adalah faktor yang dapat dikendalikan oleh perusahaan, faktor tersebut antara lain berupa keadaan produk, penetapan harga, cara-cara promosi, saluran distribusi dan kegiatan penjualan itu sendiri.

Dalam pemasaran diperlukan adanya kemampuan pengetahuan produk dan teknik menjual guna mempermudah dalam menjalankan tugasnya serta meningkatkan penjualan. Sedangkan daya juang diperlukan agar bersemangat dan mempunyai kekuatan secara spiritual serta tidak merasa bosan dan bimbang dalam pekerjaannya.

\section{TINJAUAN PUSTAKA}

Public Relations

W. Emerson Reck berpendapat public relations merupakan kelanjutan dari proses pendapatan kebijaksanaan, penentuan pelayanan dan sikap yang disesuaikan dengan kepentingan orang-orang atau golongan agar orang atau lembaga itu memperoleh kepercayaan dan good
NIAGAWAN Vol 8 No 2 Juli 2019

will dari mereka. Kedua, pelaksanaan kebijaksanaan, pelayanan dan sikap untuk menjamin adanya pegertian dan penghargaan yang sebaik-baiknya. Ini sejalan dengan apa yang dikemukakan oleh Frank Jefkin yang mengatakan Public Relations berarti menciptakan saling pengertian. Public Relations adalah suatu untuk mendapatkan sesuatu tanpa harus melakukan sesuatu. Tetapi dalam kenyataannya kita tidak akan mendapatkan apapun bila tidak berbuat sesuatu. Sekarang menjadi pertanyaan besar, apa public relations profitable atau investasi dalam kegiatan pemasaran? Menurut penulis public relations investasi jangka panjang dalam kegiatan pemasaran, hasilnya dirasakan dalam waktu yang lama selaras dengan tugas jangka panjangnya membina nama baik perusahaan, mendidik konsumen dan menciptakan citra.

\section{Pemasaran}

Pemasaran adalah bentuk tradisional yang merupakan proses perencanaan yang muncul dari pengenalan pasar oleh penelitian dan apakah yang dapat ditawarkan kepada pasar. Banyak perusahaan yang memanfaatkan dan menggunakan public relations pemasaran dalam meningkatkan kesadaran masyarakat terhadap produk baru maupun produk yang sudah mapan.

Menuruf American Marketing Association, pemasaran adalah proses perencanaan dan pelaksanaan pembuatan, pembuatan harga, promosi dan distribusi meliputi ide, produk, dan jasa untuk menciptakan pertukaran yang memberikan kepuasan kepada individu dan organisasi (Duncan, 2003). Fokus pemasaran adalah terjadinya pertukaran, antara dua pihak, keinginan untuk memberikan sesuatu, dan saling berkomunikasi satu sama lain. Konsep pemasaran ini disederhanakan oleh Kotler menjadi konsep marketing mix yaitu product, 
place, promotion dan price. Seringkali konsep marketing mix disebut 4P yaitu (1) Produk: Produk adalah tawaran untuk memuaskan kebutuhan dari perusahaan. Tawaran ini dapat berbentuk barang, jasa, atau campuran keduanya. Produk menggambarkan bagaimana perusahaan menciptakan produk yang tepat untuk pasar sasaran. Berkaitan dengan produk adalah pemberian merek, pengemasan, jaminan, pengembangan produk baru, kualitas produk dan lini produk yang ada, (2) Tempat: Tempat adalah bagaimana perusahaan membuat produk/jasanya tersedia dalam jumlah dan lokasi yang tepat ketika konsumen memerlukan produk/jasa tersebut. Untuk lebih sederhana, tempat disini dapat dipahami sebagai saluran distribusi yang akan digunakan oleh perusahaan dalam mendistribusikan produknya. Berkaitan dengan tempat adalah wholesaler (termasuk distributor, pedagang besar), retailer (pengecer), dan logistik, (3) Promosi: Promosi adalah bagaimana perusahaan mengkomunikasikan produk/jasanya kepada saluran distribusi dan pasar sasarannya untuk mempengaruhi sikap dan perilaku mereka. Promosi dibedakan menjadi 3, yaitu penjualan pribadi (personal selling), penjualan massa (mass selling), dan promosi penjualan (sales promotion), (4) Harga: Harga adalah sejumlah uang yang perlu dibayarkan konsumen untuk mendapatkan tawaran perusahaan. Jika perusahaan melihat harga sebagai pendapatan, maka konsumen melihat harga sebagai biaya. Yang perlu diperhatikan adalah tujuan penetapan harga, kebijakan harga yang digunakan, dan bagaimana menetapkan harga di dunia bisnis.

Komunikasi Pemasaran

Komunikasi adalah usaha yang dilakukan untuk menginformasikan, membujuk, mengingatkan atau menyampaikan kepada publik (konsumen) mengenai keberadaan produk maupun jasa yang dijual dan beredar di pasar
NIAGAWAN Vol 8 No 2 Juli 2019

agar dikenal, dibeli kemudian menjadi pelanggan (Muchlisin Riadi)

Sebuah konsep perencanaan komunikasi adalah mengenali nilai tambah dari perencanaan mendalam yang mengevaluasi peran strategis dari berbagai disiplin komunikasi seperti periklanan, respon langsung, sales promosi, dan hubungan masyarakat dan menggabungkannya untuk menghasilkan dampak komunikasi yang penuh dengan kejelasan, konsisten, dan maksimal (American Association of Advertising Agencies). Pendekatan yang digunakan adalah "gambar keseluruhan" yang mengenali seluruh aktivitas perusahaan seperti media iklan, harga, publisitas, penjualan promosi, penjualan langsung, dan lokasi di mana produk dijual. Contohnya, harga mahal menyimbolkan kualitas, bentuk produk, kemasan, nama merek, bahkan citra toko juga berperan terhadap komunikasi pemasaran. Konsep komunikasi pemasaran terpadu adalah menyatukan beberapa komponen komunikasi pemasaran untk menyampaikan pesan pemasaran kepada konsumen sehingga dampak yang diingikan lebih maksimal. Komunikasi pemasaran muncul karena ada perkembangan pada dunia sebagai berikut: (1) Perubahan dari media tradisional ke media lainnya. Biaya yang mahal dan tidak efektif. Persaingan harga antara perusahaan menyebabkan perusahaan memilih untuk promosi harga (2)Ada fragmentasi media massa menyebabkan munculnya media yang lebih kecil dan fokus, misalnya direct mail dan event sponsorship, (3) Globalisasi menyebabkan jaringan perusahaan menggantikan pengecer. Dengan teknologi scanner, dikenali perilaku pembelian dan diputuskan menggunakan metode promosi yang lebih efektif yaitu sales promotion, (4)Berkembangnya database marketing. Komputer menyebabkan berbagai data mulai psikografik, demografik, geografik, 
pola pembelian, pemilihan media dihimpun. Data ini mendukung metode direct marketing yang langsung pada target khalayak, (5)Perubahan pada pembelian media. Harga yang semakin mahal menuntut adanya diskon yang lebih besar dan kontrol yang lebih ketat terhadap pembelian media (Duncan, 2003).

Sedangkan Belch and Belch (2003) menambahkan bahwa perubahan dunia khususnya di bidang periklanan dan promosi seperti (1) sulitnya melakukan komunikasi yang efektif dan efisien dengan audiens sangat berpengaruh terhadap kesuksesan sebuah merek, (2) dibutuhkan sebuah komunikasi pemasaran yang menarik bagi konsumen karena konsumen tidak lagi tertarik terhadap periklanan tradisional, (3) perkembangan teknologi yang melahirkan new media sehingga media tradisional tidaklah lagi menjadi media primadona untuk melakukan komunikasi pemasaran, (4) dibutuhkan strategi yang efektif yang efisien untuk mengelola pengeluaran pemasangan iklan di media yang sangat mahal sehingga pemasar lebih menyalurkan dana pemasaran mereka pada taktik komunikasi pemasaran lainnya.

\section{METODE PENELITIAN}

Desain penelitian yang digunakan adalah dengan metode penelitian kualitatif, yaitu penelitian yang bersifat interpretatif (menggunakan penafsiran) serta melibatkan banyak metode, dalam menelaah masalah penelitiannya. Data yang dipakai dalam penelitian ini adalah menggunakan gabungan wawancara,observasi, dan dokumentasi. Dokumen (studi pustaka) ini memanfaatkan dokumen-dokumen tertulis, baik buku, surat kabar, jurnal dan data dari internet. Data Primer penelitian ini dilakukan secara indepth interview (wawancara mendalam) dengan key informant yaitu Public Relations, Guest Relations Officer, dan Banquet Sales DWS Coffee Medan. Informan selanjutnya adalah konsumen DWS Cofee Medan, ini dilakukan untuk mengetahui apakah strategi komunikasi pemasaran Public Relations dapat dikatakan sukses atau tidak dalam memberikan pelayanan kepada konsumennya. Kemudian data sekunder yang digunakan adalah dengan studi literatur beberapa referensi dokumen tertulis, baik buku, surat kabar, skripsi, jurnal dan data dari internet. Dalam penelitian ini teknik analisis data kualitatif yang peneliti gunakan adalah teknik triangulasi. Lokasi penelitian yang dilakukan oleh penulis adalah di DWS Coffe Medan, yang bertempat di Jl. Tempuling No.66 kota Medan Sumatera Utara.

\section{HASIL DAN PEMBAHASAN}

\section{Strategi Public Relations Dan Keputusan Penting Dalam Pemasaran}

Pertimbangan kapan dan bagaimana menggunakan public relations sudah harus ditentukan oleh manajemen puncak dengan menetapkan sasaran pemasaran, pemilihan pesan dan sarana public relations yang akan dipakai serta mengevaluasi hasil public relations dalam satu konsep pemasaran. Sedangkan menetapkan sarana pemasaran dapat dibantu oleh public relations dengan:

1. Menciptakan kesadaran dengan memuat berita sebuah produk, pelayanan,tokohtokoh yang menunjang

2. Membangun kredibilitas dengan mengkomunikasikan pesan dalam konteks editorial

3. Memotivasi tenaga penjualan, melatih dan mengembangkan

4. Menekan budget promosi, kerana biaya public relations lebih rendah dari pada biaya periklanan, maka dengan tujuan untuk 
menekan biaya akan merupakan alasan kuat untuk menggunakan public relations agar dapat memper-oleh share of mind.

Praktisi public relations mengembangkan banyak kisah yang menarik yang bercerita sekitar produk, juga dapat ditunjang dengan banyak ide yang orisinal untuk mengembangkan acara-acara yang berbeda yang dilakukan oleh pesaing.

\section{Perbedaan Tujuan Antara Pemasaran dan Public Relations Dan Dengan Iklan}

Penasaran tujuan jangka pendek, tujuan jangka pendeknya adalah meningkatkan penjualan, meng-umumkan penyempurnaan produk atau peluncuran produk baru, mengumumkan penunjukan agen baru. Sedangkan public relations tujuan jangka, tujuan jangka panjang adalah membina nama baik perusahaan, mendidik konsumen, menciptakan citra. Perbedaan dan persamaan public Relations dengan iklan. Persamaannya iklan dan public relations mempunyai kekuatan yang berbeda. Citra perusahaan secara keseluruhan terbentuk dari gabungan sesuatu yang tidak terhitung, tetapi perbedaan produknya dan iklan tetap ada, sehingga iklan akan terintergrasi dengan promosi, nama, gaya dan simbol-simbol lainnya dalam perusa-haan sudah termasuk dalam kegiatan public relations.

Beberapa bentuk iklan seperti iklan keuangan, paling sering dipakai dalam kegiatan public relations. Akibat dari hasil penjelasan dari dalam, seperti laporan akuntansi, laporan perusahaan biasanya dilakukan sesering mungkin sesuai dengan gaya public relations yang dipakai di dalam perusahan.

\section{Proses Perencanaan Public Relations Dalam}

\section{Pemasaran}

Dalam proses perencanaan public relations pada kegiatan pemasaran yang pertama dilakukan adalah menentukan sasaran
NIAGAWAN Vol 8 No 2 Juli 2019 penerima selanjutnya menentukan Tujuan, kemudian terus melakukan menentukan pesan yang ingin disampaikan dan formatnya dan selanjutnya melakukan pelaksanaan dan evaluasi.

\section{KESIMPULAN DAN SARAN}

Setiap perusahaan yang ingin mencapai sukses, selalu berusaha memasarkan produknya yang dihasilkan dengan baik, Pemasaran selalu mendapat perhatian yang lebih dengan tanpa mengabaikan kegiatan-kegiatan lain seperti produksi,keuangan, personalia dan lain sebagainya. Dalam era yang sangat kompetitif dan banyak pemain dalam memasarkan produknya, setiap perusahaan kini menggunakan kegiatan public relations, sehingga melahirkan apa yang kita kenal dengan kegiatan marketing public relations.

\section{REFERENSI}

Belch and Belch. (2003) Advertising And Promotion, 6th Edition. McGraw-Hill.

Duncan, Tom. (2003). Principles Advertising And IMC. Sydney: Mcgraw Hill, 2003

Efendy, O. Onong, "Hubungan Insani”, Remaja Karya, Jakarta, 1988.

Jepkins, Frank, "Public Relations Untuk Bisnis", Pustaka Binaman Pressindo, Jakarta, 1994.

Riadi M, “ Pengertian, Bauran, Dan Strategi Komunikasi Pemasaran”, https://www.kajianpustaka.com/2018/11/p engertian-bauran-dan-strategikomunikasi-pemasaran.html 